\title{
Modeling the above and belowground biomass of planted and coppiced Eucalytpus globulus stands in NW Spain
}

\author{
Daniel J. Vega-Nieva ${ }^{1}$ (D) Enrique Valero ${ }^{2} \cdot$ Juan Picos $^{2} \cdot$ Enrique Jiménez $^{3}$
}

Received: 26 March 2014 / Accepted: 4 June 2015 / Published online: 9 July 2015

(C) INRA and Springer-Verlag France 2015

\begin{abstract}
- Key message The study developed equations for predicting aboveground and belowground biomass of planted and coppiced Eucalyptus globulus in NW Spain. It was the first published work considering site effects on aboveground biomass and first work for predicting root biomass, for this species in this region, where it covers about 310,000 ha.

- Context Eucalyptus globulus is a species of great economic relevance, being increasingly used for bioenergy. In Galicia (NW Spain), where most of the E. globulus in the country is growing, there are scarce studies modeling aboveground biomass fractions of that species, together with a lack of information on its belowground biomass.

- Aims The objective of this study was to develop new and more accurate allometries for predicting E. globulus tree aboveground biomass fractions and coarse belowground biomass in NW Spain.
\end{abstract}

Handling Editor: Erwin Dreyer

Contributions of the co-authors Dr. Enrique Valero and Dr. Juan Picos from the University of Vigo, Spain, planned the experimental work of the current study and contributed to data analysis.

Dr. Enrique Jimenez from the Lourizan Forest Research Centre, XuntaGovernment of Galicia, Spain, contributed to field sampling and statistical data analysis of the current work.

Daniel J. Vega-Nieva

DanielJVN@gmail.com

1 Faculty of Forest Sciences, Universidad Juárez del Estado de Durango, Río Papaloapan y Blvd. Durango S/N Col. Valle del Sur, CP 34120 Durango, Dgo, Mexico

2 Faculty of Forest Engineering, Universidad de Vigo, Vigo, Spain

3 Centro de Investigaciones Forestales de Lourizán, Consellería de Medio Rural y Mar, Xunta, Government of Galicia, A Coruña, Spain
- Methods Aboveground biomass models were calibrated by two approaches: nonlinear seemingly unrelated regressions (NSUR), using tree and stand variables, and nonlinear mixed effects (nlme) equations adding the site factor effect. Validation was made with an independent dataset (85 trees). Belowground biomass equations were constructed for planted and coppiced trees.

- Results Crown length and dominant height substantially improved the precision in leaf and branch biomass estimation (NSUR). An added value of our study was the modeling of root/shoot ratio, as a function of diameter of planted and coppiced trees, for first time in this species.

- Conclusion This study confirms the importance of site and stand stage to explain aboveground biomass variability. Although different belowground biomass accumulation patterns were observed for planted and coppice trees, aboveground biomass equations were common.

Keywords Eucalyptus globulus plantations · Coppice · Allometries $\cdot$ Aboveground biomass $\cdot$ Belowground biomass

\section{Introduction}

A rapid expansion of Eucalyptus plantations, occupying an area of approximately $14,000 \mathrm{~km}^{2}$ in southern Europe, has occurred in the last decades (Pérez-Cruzado et al. 2011). Eucalyptus globulus, the most widespread used species in fastgrowing plantations in Spain and Portugal, is managed in short rotations, usually of $12-15$ years, and frequently regenerated by coppicing (Merino et al. 2005). In the region of Galicia, NW Spain, where most of the E. globulus in the country is growing, plantations of this species comprise $20 \%$ of the total forest area (DGCN 2012), providing with about of $60 \%$ to the timber yield in the region. As well as its 
traditional use for pulpwood, this species is increasingly being utilized as a bioenergy feedstock for renewable heat and electricity production in Spain and Portugal (Vega-Nieva et al. 2008; Viana et al. 2010, 2012; Pérez-Cruzado et al. 2011), mainly through the combustion of harvesting debris and bark. There is also a growing interest in the utilization of the exhausted coppice root system as a biomass feedstock. In addition, eucalypt plantations are, by far, the major contributors to carbon storage and sequestration by the Galician forests (Pérez-Cruzado et al. 2011). Therefore, it is of highest importance to have accurate estimates of the biomass in eucalypt stands in that region.

A number of studies have recently been developed to estimate E. globulus tree total aboveground biomass and its components (stem wood, bark, branches, leaves) in the Iberian Peninsula (e.g., Montero et al. 2005; Ruiz-Peinado et al. 2012; Soares and Tomé 2012; Herrero et al. 2014) and elsewhere (O'Grady et al. 2006; Zewdie et al. 2009). Antonio et al. (2007) carried out a comprehensive study to estimate aboveground biomass components for that species in Portugal, including tree and stand explanatory variables. The ample area of study largely embraced climatic conditions with less precipitation and higher temperatures than those of Galicia eucalypt stands (AEMET-Gobierno de España and Instituto de Meteorología de Portugal 2011). In Galicia, Merino et al. (2005) estimated biomass components at harvesting age using also tree and stand variables focused on tree biomass at the end of the rotation period. Brañas et al. (2000) and Pérez-Cruzado et al. (2011) constructed equations with only tree variables, based on a sampling that did not consider the Galician western area of eucalypt. The three latter studies did not take into account both the hierarchical structure of data and the influence of site factor on biomass components explicitly (Smith et al. 2014). This is relevant in Galicia, where there is a climatic gradient potentially affecting eucalypt biomass allocation patterns. In spite of its critical importance for carbon and nutrient cycles and their growing utilization as biomass fuel, the belowground biomass allocation of E. globulus trees, as in other forest species, remains largely unknown (Resh et al. 2003; O'Grady et al. 2006; Herrero et al. 2014).

The objectives of this work were as follows: (1) to develop new and more accurate allometries for predicting E. globulus aboveground biomass fractions (stem, branch, and leaf biomass) in NW Spain, considering tree and stand variables, and taking into account the site effect; (2) to validate the predictions from those allometries with independent data and to compare their performance with existing allometries for predicting E. globulus aboveground biomass fractions; and (3) to develop allometries for predicting coarse belowground biomass of planted and coppiced E. globulus trees in NW Spain.

\section{Materials and methods}

\subsection{Aboveground biomass sampling}

The study was carried out in the region of Galicia (NW of Spain). The location, tree, and stand characteristics and number of trees sampled in each of the sites of study are shown in Table 1, which includes a summary of the main characteristics of the studies considered for comparison. Site locations both for calibration and validation tasks were subjectively chosen in order to represent the range of main conditions in which E. globulus grows in Galicia. Total annual precipitation in the study sites ranged from 1350 to $2400 \mathrm{~mm}$, mean average annual temperature from 12.5 to $17.5^{\circ} \mathrm{C}$. Regional meteorological service (Meteogalicia) to study site elevation ranged from 53 to $226 \mathrm{~m}$. Soils varied in depth $(0.2-1.7 \mathrm{~m})$ and are mainly loam and sandy loam soils developed on different parent material according to the site (granite, gneiss, schist, sedimentary, and slate). At each plot, at least two per site (of a minimum size of $314 \mathrm{~m}^{2}$ ), the diameters at breast height $(d, \mathrm{~cm})$ and total height $(h, \mathrm{~m})$ of all trees were measured for the determination of plantation density (stem/ha), stand dominant height $(\mathrm{m})$ - the mean height of the 100 thickest trees per hectare, depending on plot size (Pardé and Bouchon 1988) and stand basal area $\left(\mathrm{m}^{2} / \mathrm{ha}\right)$. Three to four trees were proportionally selected in each plot for destructive biomass sampling according to the diameter distribution. Stand type (coppice or planted) and tree age were recorded. The number of shoots per hectare was considered as the tree density on coppice stands.

A total of 230 trees (145 for calibration and 85 for validation, including a total of 68 coppice trees), as shown in Table 1 , were felled on the study sites during autumn. Diameters at breast height, total height, and height of the live crown - defined as the point on the stem of the lowest live branch above which there were at least two consecutive live brancheswere measured after felling. Biomass was partitioned into different categories, comprising leaves plus twigs $(<0.6-\mathrm{cm}$ diameter), small (0.6-2-cm diameter), medium (2-7-cm diameter), and large ( $>7-\mathrm{cm}$ diameter) live branch size classes, dead branches, and stem. The end top of the stem $(<7-\mathrm{cm}$ diameter $)$ was added to the branch fraction. The fresh weight of these materials was obtained to the nearest $50 \mathrm{~g}$ with a tripodsuspended field scale, and representative subsamples of crown components were selected from the upper, middle, and lower sections of the crown and weighed in the field. The stem was divided into $\operatorname{logs}$ of $0.5 \mathrm{~m}$ long and subsequently weighed to the nearest $100 \mathrm{~g}$. Three wood disks of $3 \mathrm{~cm}$ thick were cut from each stem at regular intervals. The disks and the representative branch and leaf subsamples were transported in sealed plastic bags to the laboratory and used to determine the moisture content of each fraction and size category by oven-drying at $65{ }^{\circ} \mathrm{C}$ during $48 \mathrm{~h}$. Twig and leaf material were separated in the laboratory, and dry weights of stem, 
Table 1 Location and main dasometric characteristics of the sites of study for aboveground and belowground biomass measurement and of the literature studies considered for comparison of aboveground biomass predictions

\begin{tabular}{|c|c|c|c|c|c|c|c|c|c|c|c|}
\hline $\begin{array}{l}\text { Biomass } \\
\text { component }\end{array}$ & Data & Site $N$ & $\begin{array}{l}\text { Planted/ } \\
\text { coppice }\end{array}$ & $\begin{array}{l}N \text { plots } \\
\text { by site }\end{array}$ & $\begin{array}{l}N \text { trees } \\
\text { by site }\end{array}$ & $X$ & $Y$ & $N($ stem $/$ ha $)$ & Age (years) & $h_{\mathrm{dom}}(\mathrm{m})$ & $G\left(\mathrm{~m}^{2} / \mathrm{ha}\right)$ \\
\hline \multirow[t]{26}{*}{ Aboveground } & \multirow{12}{*}{$\begin{array}{l}\text { Model } \\
\quad \text { calibration }\end{array}$} & 1 & Planted & 3 & 13 & 586.5 & 4.810 .250 & $1100-1250$ & $5.5-7.0$ & $9.5-12.2$ & $8.1-10.7$ \\
\hline & & 2 & Coppice & 3 & 10 & 541.3 & 4.697 .500 & $800-1150$ & $5.5-7.3$ & $8.7-20.3$ & $4.2-22.0$ \\
\hline & & 3 & Planted & 5 & 16 & 569.5 & 4.767 .500 & $1050-1300$ & $5.5-11.3$ & $11.4-23.0$ & $9.6-21.0$ \\
\hline & & 4 & Planted & 5 & 17 & 505.8 & 4.700 .550 & $900-1150$ & $5.9-10.7$ & $6.6-22.7$ & $2.3-24$ \\
\hline & & 5 & Planted & 3 & 9 & 534.4 & 4.750 .050 & $700-1050$ & $5.9-7.1$ & $6.9-11.1$ & $2.3-7.7$ \\
\hline & & 6 & Planted & 5 & 16 & 513.1 & 4.680 .270 & $800-1300$ & $7-10.7$ & $10.1-22.2$ & $7.3-23.7$ \\
\hline & & 7 & Coppice & 3 & 11 & 655 & 4.822 .500 & $1100-1350$ & $7.3-11.3$ & $14.6-26.3$ & $8.3-26.2$ \\
\hline & & 8 & Coppice & 3 & 11 & 523.9 & 4.623 .080 & $950-1250$ & $10.2-12.3$ & $16.7-28.1$ & $21.5-31.1$ \\
\hline & & 9 & Planted & 3 & 12 & 641.5 & 4.798 .750 & $1000-1350$ & $10.3-14.3$ & $14.7-24.9$ & $12.4-29.4$ \\
\hline & & 10 & Planted & 3 & 10 & 545.1 & 4.775 .980 & $850-1000$ & $9.3-30$ & $20.1-32.8$ & $15.6-52.1$ \\
\hline & & 11 & Coppice & 3 & 12 & 584.8 & 4785.81 & $1050-1150$ & $9.3-25$ & $19.7-31.5$ & $16.5-59.1$ \\
\hline & & 12 & Planted & 2 & 8 & 508.4 & 4.740 .700 & $1000-1200$ & $8.5-22$ & $15.8-24.7$ & $12.1-45.5$ \\
\hline & $\begin{array}{l}\text { Total model } \\
\text { calibration }\end{array}$ & 12 & & 41 & 145 & & & $700-1350$ & $5.5-30$ & $6.6-32.8$ & $2.3-59.1$ \\
\hline & \multirow[t]{7}{*}{ Model comparison } & 13 & Planted & 5 & 17 & 531 & 4681.22 & $700-1200$ & $6.2-11.4$ & $9.3-22.4$ & $3.7-27.1$ \\
\hline & & 14 & Planted & 3 & 10 & 521.5 & 4.762 .000 & $1150-1300$ & $7.5-9.9$ & $13.9-20.5$ & $9.4-27.6$ \\
\hline & & 15 & Coppice & 4 & 12 & 592 & 4.386 .050 & $1000-1350$ & $6.5-23$ & $17.5-27.4$ & $12.5-51.3$ \\
\hline & & 16 & Planted & 3 & 10 & 510.8 & 4.663 .090 & $900-1100$ & $6.7-25.5$ & $14.3-30.9$ & $14.8-43.4$ \\
\hline & & 17 & Coppice & 4 & 12 & 609.8 & 4.834 .925 & $900-1200$ & $7.5-21.3$ & $17.6-28.9$ & $13.7-42.6$ \\
\hline & & 18 & Planted & 3 & 11 & 573.5 & 4.750 .350 & $1100-1300$ & $8.7-15.5$ & $14.8-22.1$ & $13.1-45.3$ \\
\hline & & 19 & Coppice & 3 & 13 & 563.2 & 4.794 .050 & $1000-1300$ & $8.5-29$ & $18.7-34.2$ & $13.4-52.2$ \\
\hline & $\begin{array}{l}\text { Total model } \\
\text { comparison }\end{array}$ & 7 & & 25 & 85 & & & $700-1350$ & $6.2-29$ & $9.3-34.2$ & $3.7-52.2$ \\
\hline & Total aboveground & 19 & & & 230 & & & $700-1350$ & $5.5-30$ & $6.6-34.2$ & $2.3-59.1$ \\
\hline & Ref 1 & 9 & & & 30 & N Spain & & $446-1825$ & $6.0-18$ & $1.1-22.8$ & $0.1-27.8$ \\
\hline & Ref 2 & 6 & & & 78 & N Spain & & $1147-2400$ & $13-24$ & $21.6-35.6$ & $22.3-49.6$ \\
\hline & Ref 3 (planted) & 26 & & & 254 & Portugal & $563-3240$ & $0.5-19$ & $1.8-37.3$ & $0.0-51.8$ & \\
\hline & Ref 3 (coppice) & 6 & & & 187 & Portugal & & $1605-6400$ & $2.5-13.0$ & $4.5-31.6$ & $4.5-32.9$ \\
\hline \multirow[t]{8}{*}{ Belowground } & \multirow[t]{3}{*}{ Planted } & 1 & Planted & 3 & 12 & 544.5 & 4.650 .100 & $1000-1300$ & $9.4-18.5$ & $20.9-43.6$ & $18.2-46.8$ \\
\hline & & 2 & Planted & 4 & 15 & 500.6 & 4.775 .010 & $900-1200$ & $9.9-17.7$ & $22.6-45.4$ & $20.4-51.6$ \\
\hline & & 3 & Planted & 2 & 9 & 634.5 & 4.826 .550 & $850-1000$ & $9.7-17.5$ & $21.7-36$ & $19.2-32.3$ \\
\hline & Total planted & 3 & Planted & 9 & 36 & & $1000-1300$ & $9.4-18.5$ & $20.9-45.4$ & $18.2-51.6$ & \\
\hline & \multirow[t]{3}{*}{ Coppice } & 4 & Coppice & 3 & 11 & 512.6 & 4.720 .510 & $2000-4500$ & $9.5-14.7$ & $21.0-45.8$ & $18.3-37.6$ \\
\hline & & 5 & Coppice & 2 & 6 & 534.5 & 4.730 .100 & $1800-5500$ & $10.5-14.2$ & $21.3-41.1$ & $18.6-45.4$ \\
\hline & & 6 & Coppice & 4 & 14 & 510.8 & 4.770 .100 & $3000-4250$ & $10.1-13.5$ & $23.4-35.5$ & $21.4-32$ \\
\hline & Total coppice & 3 & Coppice & 9 & 31 & & $1800-5500$ & $9.5-14.7$ & $21.0-45.8$ & $18.3-45.4$ & \\
\hline
\end{tabular}

Refs 1, 2, and 3 are studies of Pérez-Cruzado et al. (2011), Merino et al. (2005), and Antonio et al. (2007), respectively $N$ (stem/ha) stand density (stem/ha), $h_{d o m}$ dominant height $(\mathrm{m}), G$ basal area $\left(\mathrm{m}^{2} / \mathrm{ha}\right)$

branches, and leaves were calculated from the moisture content of the representative subsamples.

\subsection{Belowground biomass sampling}

Destructive total belowground biomass sampling was conducted during autumn for 36 planted and 31 coppice trees at six additional sites, basically following the guidelines of
Snowdon et al. (2002) and the recommendations from Resh et al. (2003) and Jonson and Freudenberger (2011). The site location and the main tree and stand characteristics, together with the number of trees sampled at each site, are shown in Table 1 . The coarse roots, defined as all live and dead belowground biomass $>2 \mathrm{~mm}$ in diameter, were sampled with a full Voronoi trench excavation down to bedrock with a mechanical excavator, with generally a surface area of $3 \times 3 \mathrm{~m}$ centered at 
each tree stump. After the removal of the intact root-ball and placement into a trailer for transport, the excavator was used to remove the soil and roots in the trench area. Roots were separated from soil by a combination of wet sieving with a 2-mm sieve and hand sorting of soil, as recommended by Resh et al. (2003) and Levillain et al. (2011). Coarse roots were sorted into three size categories: medium $(2-10 \mathrm{~mm})$, large $(10$ $30 \mathrm{~mm})$, and very large $(30-60 \mathrm{~mm})$. In addition, the rootball and the larger root portions attached to the root-ball were also measured separately. Roots were stored in large plastic bags, transported to the research station the same day of collection, and stored in a cool room $\left(5^{\circ} \mathrm{C}\right)$. Root samples were oven-dried to constant mass at $65{ }^{\circ} \mathrm{C}$ during $48 \mathrm{~h}$, and subsamples for each tree were ground and combusted at $550{ }^{\circ} \mathrm{C}$ for soil contamination mass correction. Aboveground biomass was also obtained with the same protocols above described to calculate root/shoot $(\mathrm{R} / \mathrm{S})$ ratio, although was not used to develop the allometries for aboveground biomass.

\subsection{Data analysis}

\subsubsection{Aboveground biomass}

Model calibration Two different approaches were used to develop aboveground biomass component equations. The first approach was performed in two stages: in the first one, individual fitting models were derived for each component; in the second one, additive biomass equations were obtained utilizing the nonlinear seemingly unrelated regression (NSUR) method. For the individual equations, the minimum generalized squares in the MODEL procedure of SAS/STAT ${ }^{\mathbb{B}}$ (SAS Institute, Inc 2004) were utilized. Heteroscedasticity was assessed by representing the unweighted residuals against the observed values. It was corrected by weighted fitting (Parresol 2001) utilizing the inverse of the variance of the residuals assigned at each observation as a weighting factor (Harvey 1976). The models used were in order of complexity:

$$
\begin{aligned}
& W=k^{*} d^{\mathrm{a}}+\varepsilon \\
& W=k^{*} d^{\mathrm{a}} X^{\mathrm{b}}+\varepsilon \\
& W=k^{*} d^{\mathrm{a}} Y^{\mathrm{b}}+\varepsilon
\end{aligned}
$$

where $W$ represents the dry mass of leaf, branch, and stem biomass; $d$ is the diameter at breast height; $X$ independent tree variables (tree height, crown length); $Y$ independent stand variables (age, basal area); $k, a$, and $b$ are the parameters to be estimated; and $\varepsilon$ is the error term. Models previously reported for the same species (Merino et al. 2005; Antonio et al. 2007; Pérez-Cruzado et al. 2011) were also constructed.
Goodness of fittings was evaluated by the coefficient of determination $\left(R^{2}\right)$, defined as the square correlation coefficient between the measured and estimated values, root-meansquare error (RMSE) values, model bias ( ), model precision $(|r|)$, and efficiency values $(E)$ (e.g., Myers 1990; Antonio et al. 2007).

Model bias was evaluated with the mean of the press residuals, and model precision $|r|$ was evaluated with the mean of the absolute values of the press residuals (e.g., Myers 1990).

Model efficiency was obtained following Soares et al. (1995) as follows:

$E=1-\operatorname{average}\left(e^{2}\right) / \operatorname{average}\left(o^{2}\right)$

where $e$ are the residuals obtained from fitting and $o$ is the difference between the observed values and the average of observed values.

The second approach was based on nonlinear mixed effects (nlme) models taking into account the hierarchical, nonlinear, and heteroscedastic structure of the data (Parresol 1999, 2001). The equations were fitted using the nlme procedure (Pinheiro and Bates 2000) with the nlme package (Pinheiro et al. 2012; R Core Team 2012). Allometric equations relating the dry mass of each biomass fraction (leaves, branches, and stem) and total biomass to tree and stand level variables and site were fitted by maximum likelihood methods using the next models:

$$
\begin{aligned}
& W=k^{*} d^{(a 01+\alpha)}+\varepsilon \\
& W=k^{*} d^{(a 01+\alpha)} X^{\mathrm{b}}+\varepsilon \\
& W=k^{*} d^{(a 01+\alpha)} Y^{\mathrm{b}}+\varepsilon
\end{aligned}
$$

where $W$ represents the dry mass of leaves, branches, stem, and total biomass; $d$ is the diameter at breast height; $X$ independent tree variables (tree height, crown length); $Y$ independent stand variables (age, basal area, dominant height); $k, a_{01}$, and $b$ are parameters to be estimated for the fixed effects; $\alpha$ is the random effect of the site for the variable $d$; and $\varepsilon$ is the error term (Smith et al. 2014). A "power of covariate" variance function was used to model the variance structure of the within-site errors for all functions - weighting factor (Pinheiro and Bates 2000). The random effect and variance function reflect site level deviations from the fixed effects, not being explicitly stated in the final function. The Akaike information criteria (AIC), model efficiency, and the RMSE were used to determine the best model for each biomass fraction. In order to keep modeling as simple as possible, additivity was not considered in this approach. However, when applying the models, the sum of the tree components resulted only in an average of $0.3 \%$ higher tree biomass compared to the total tree equation. The significance of the random term was evaluated through 
the likelihood ratio test comparing the model with and without the factor. However, as the site random effect reflects in this case the experimental design, it was included in the model whether significant or not.

In the case of coppice trees, equivalent diameter at breast height $(d e q)$-defined as the diameter at breast height with the same basal area as the sum of the basal areas of all the stems from that tree- was used.

A likelihood ratio test for detecting differences between aboveground biomass equations for coppice and planted trees was used. The test compares a full model with different set of parameters for each type of stand (coppice/planted) including a dummy variable, to a reduced model without considering the type of stand.

\section{Model validation and comparison with literature} models To validate the best constructed model, the aboveobtained aboveground biomass allometries were tested with an independent dataset of 85 trees sampled at sites 13-19 (Table 1).

To assess the performance of different equations for predicting biomass components of E. globulus in the northwestern Iberian Peninsula, we firstly compared the predictions of the equations obtained by Merino et al. (2005), Antonio et al. (2007), and Pérez-Cruzado et al. (2011) using as inputs the same data employed in the validation, with the predictions of our own equations. Additionally, we constructed equations with the same explanatory variables selected by the mentioned authors, using as inputs the dataset of the calibration. Their predictions with the validation dataset were again compared with above models.

Model performance was assessed by the coefficient of determination $\left(R^{2}\right)$, defined as the square correlation coefficient between the measured and estimated values, RMSE values, and model efficiency values.

\subsubsection{Belowground biomass}

Allometries were derived for the coarse root biomass $\left(W_{\mathrm{R}}\right)$ and the root to shoot ratio $(\mathrm{R} / \mathrm{S})$ - the ratio of root weight to total aboveground biomass - separately for planted and coppiced stands. Independent variables considered were tree diameter at breast height $(d)$ for the prediction of $W_{\mathrm{R}}$ and $\mathrm{R} / \mathrm{S}$ of planted trees and equivalent diameter at breast height (deq) for coppiced trees. Different allometric models were tested selecting the best based on the coefficient of determination $\left(R^{2}\right)$ and RMSE values and model efficiency values. Heteroscedasticity was corrected similarly to aboveground biomass fitting. A likelihood ratio test for detecting differences between belowground biomass equations for coppice and planted trees. In this case, the test compares a full model with different set of parameters for each type of stand (coppice/planted) including a dummy variable to a reduced model without considering the type of stand.

\section{Results}

\subsection{Aboveground biomass allometries: calibration}

Measured leaf, branch, and stem biomass values are shown in Fig. 1, against tree diameter of the measured trees for aboveground biomass allometry development. Crown length is shown against height to diameter and dominant height of the 145 trees in Fig. 1, showing a tendency to increase at lower height to diameter values. The regression parameters and goodness of fit of the individual weighted regression models and of the simultaneous weighted adjustment models for aboveground biomass components are shown in Tables 2 and 3. For the two approaches, significant differences were not observed between aboveground biomass equations for coppices and planted trees.

For the NSUR approach (without considering the models constructed following previous studies), the best model included diameter at breast height for all tree biomass components together with crown length for leaf and branch components and total height for stem as explanatory variables. Reasonably, good fittings were found for all the biomass components. The consideration of crown length for leaves and branches and height for stem, in addition to tree diameter, leads to reduced RMSE values, increasing $R^{2}$, and the model efficiency.

For the nlme approach, the best models included the same predictor variables than those of NSUR approach for all biomass components (Tables 2 and 3). The random effect was only significant for leaves and branches. Its inclusion reduced the AIC value from 543 to 521 for leaves and from 729 to 702 for branches. The efficiency and the coefficients of determination between observed and predicted were slightly lower than those in the NSUR approach.

The inclusion of dominant height in the diameter parameter (a) following the modeling approach of Antonio et al. (2007) generally implied an improvement in the fitting of the calibration data (Tables 2 and 3). Scatter plots of predicted versus observed values for different biomass components for this model are presented in Fig. 2.

\subsection{Aboveground biomass allometries: validation and comparison with other models}

The goodness of fit statistics of the various models compared are shown in Table 3. In general, equation constructed with the dataset of calibration following the modeling approach of Antonio et al. (2007) provided the best estimates for all biomass components, in terms of $R^{2}$, RMSE, and model 
Fig. 1 Observed leaf, branch, and stem (wood and bark) biomass and crown length values of the model calibration trees $(n=145 \mathrm{~s}) . d$ diameter at breast height $(\mathrm{cm}), h$ tree height $(\mathrm{m}), c l$ tree crown length $(\mathrm{m}), h / d$ tree height $(\mathrm{m})$ to diameter $(\mathrm{cm}), h_{d o m}$ dominant height $(\mathrm{m}), \mathrm{Wl}$ leaf biomass (kg, dry matter), $\mathrm{Wb}$ branch biomass (kg, dry matter), Ws stem biomass (kg, dry matter)
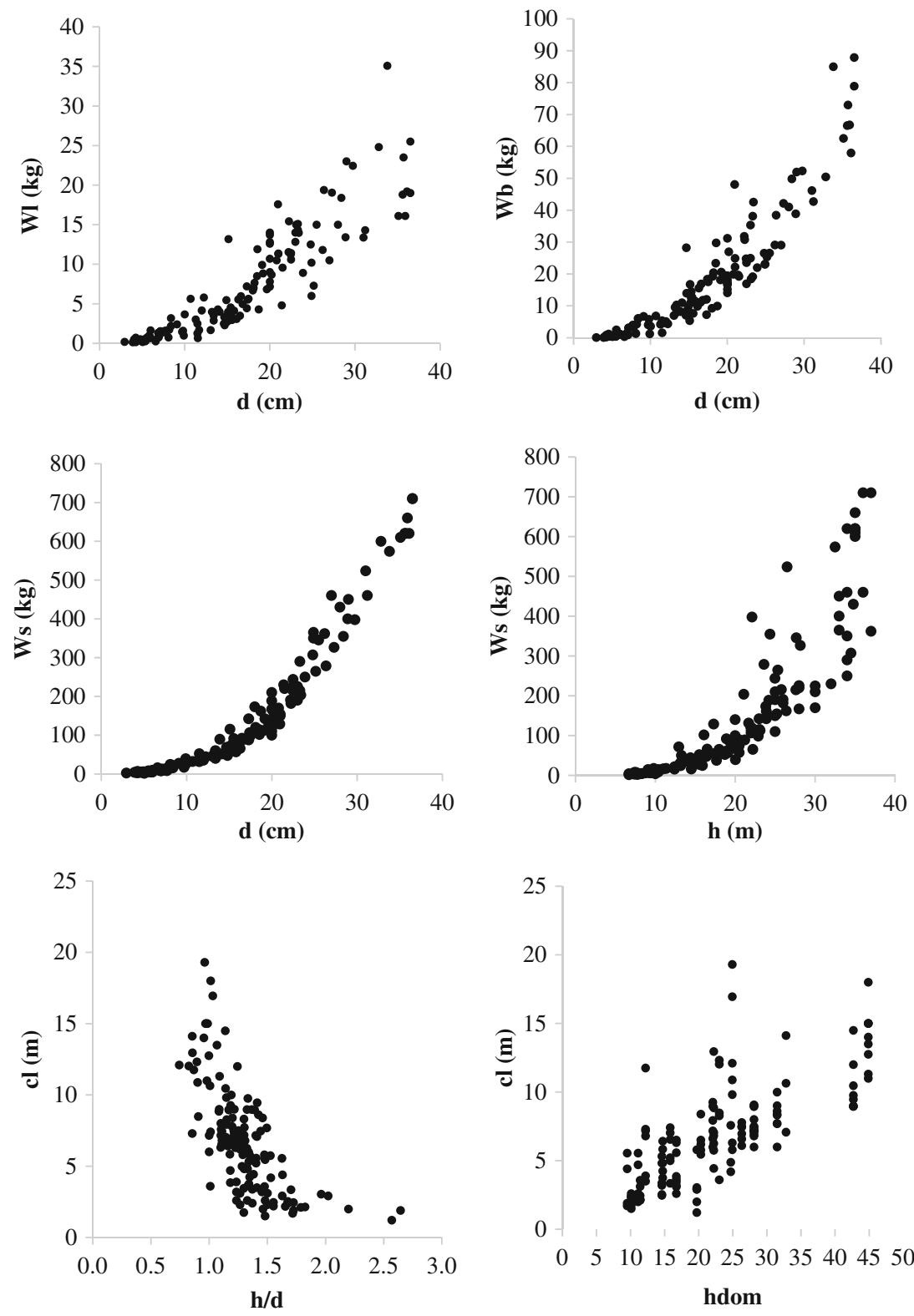

efficiency. Scatter plots of observed values as a function of predicted values obtained from this model are presented in Fig. 3 for leaves and branches.

\subsection{Belowground biomass allometries for planted and coppiced stands}

Significant differences were observed between belowground biomass equations for coppice and planted trees. The parameters and goodness of fit statistics of the derived allometries for prediction of belowground biomass and $\mathrm{R} / \mathrm{S}$ ratios of planted and coppiced stands are shown in Table 4. The measured and predicted belowground biomass values and $\mathrm{R} / \mathrm{S}$ ratios as a function of tree diameter for planted and coppiced trees are shown in Fig. 4. It can be seen that higher belowground biomass and higher R/S ratios were observed for coppiced stands.

\section{Discussion}

\subsection{Aboveground biomass allometries: calibration}

Although diameter at breast height was the best explanatory variable for all biomass components, the inclusion of other dendrometric (crown length and height) and stand variables (basal area and dominant 


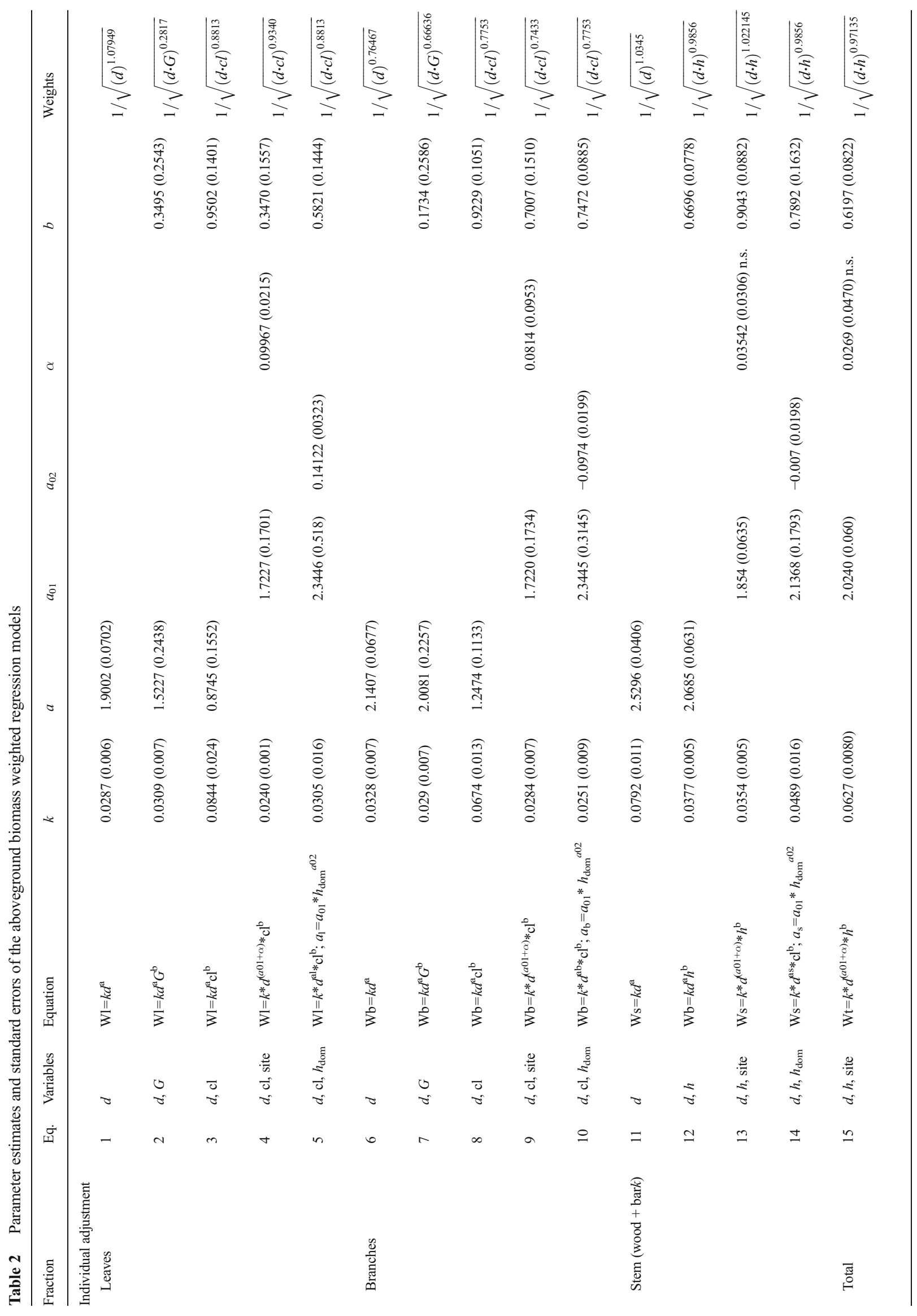




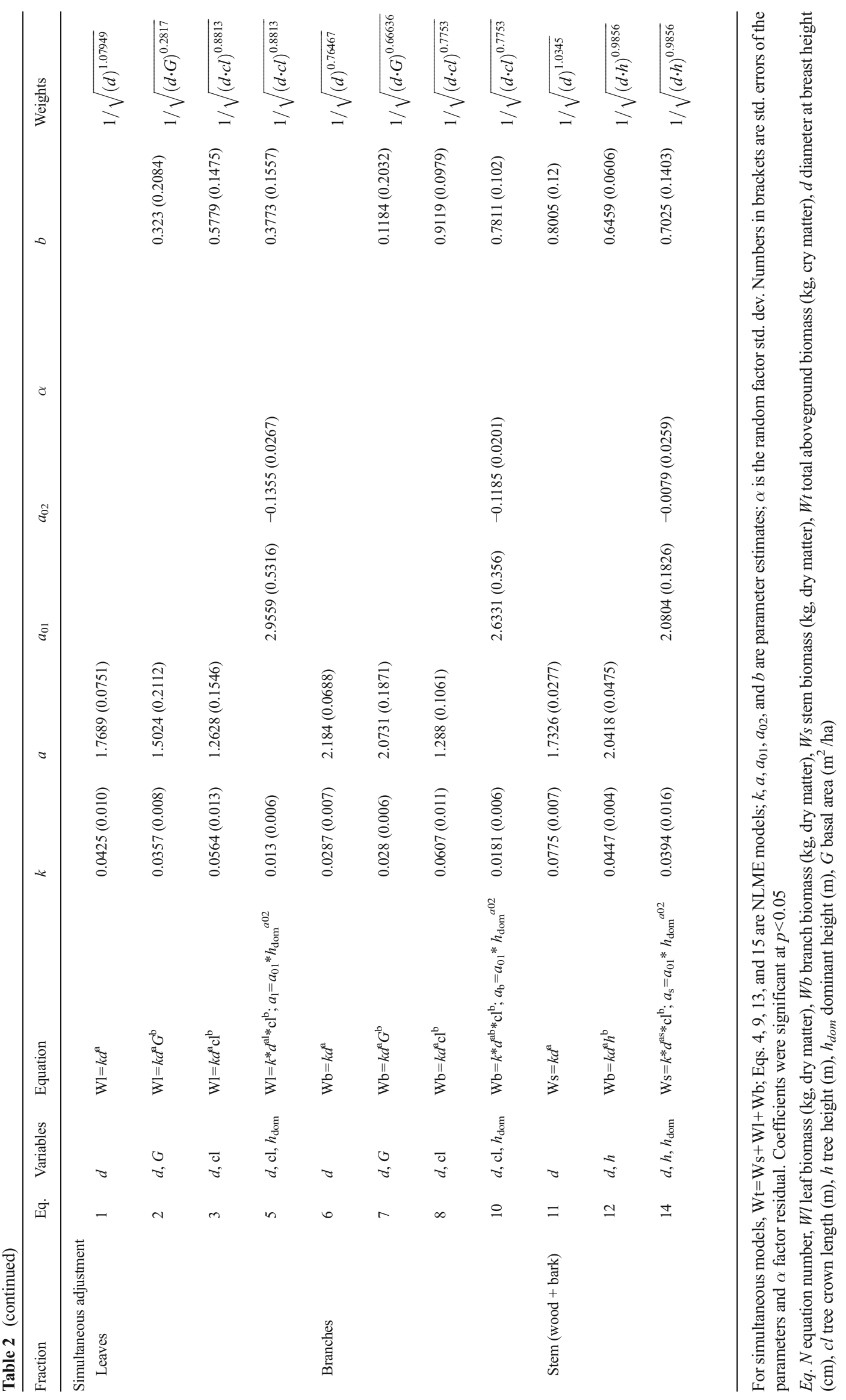

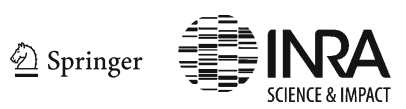


Table 3 Goodness of fit statistics of the aboveground biomass weighted regression models

\begin{tabular}{|c|c|c|c|c|c|c|c|c|c|c|}
\hline Dataset & Adjustment & Component & Eq.N. & $\begin{array}{l}\text { Variables considered } \\
\text { in the allometry }\end{array}$ & $E$ & $R^{2}$ & & $|r|$ & RMSE & AIC \\
\hline \multirow[t]{2}{*}{ Model calibration } & \multirow[t]{15}{*}{ Individual } & \multirow[t]{5}{*}{ Leaves } & 1 & $d$ & 0.816 & 0.855 & -0.22 & 1.9 & 3.1 & \\
\hline & & & 2 & $d, G$ & 0.838 & 0.896 & -0.22 & 1.9 & 2.9 & \\
\hline \multirow[t]{24}{*}{$(n=145)$} & & & 3 & $d, \mathrm{cl}$ & 0.851 & 0.899 & -0.10 & 1.8 & 2.7 & \\
\hline & & & 4 & $d$, cl, site (NLM) & 0.855 & 0.875 & -0.82 & 2.0 & 2.8 & 521.3 \\
\hline & & & 5 & $d, \mathrm{cl}, h_{\mathrm{dom}}$ & 0.864 & 0.910 & -0.61 & 1.9 & 2.6 & \\
\hline & & Branches & 6 & $d$ & 0.913 & 0.915 & -0.28 & 3.6 & 5.6 & \\
\hline & & & 7 & $d, G$ & 0.925 & 0.924 & 0.87 & 3.5 & 5.0 & \\
\hline & & & 8 & $d, \mathrm{cl}$ & 0.936 & 0.932 & 0.66 & 3.0 & 4.5 & \\
\hline & & & 9 & $d, \mathrm{cl}$, site (NLM) & 0.945 & 0.937 & -2.73 & 5.0 & 3.8 & 701.9 \\
\hline & & & 10 & $d, \mathrm{cl}, h_{\mathrm{dom}}$ & 0.957 & 0.942 & -0.20 & 3.1 & 4.4 & \\
\hline & & Stem (wood + bark) & 11 & $d$ & 0.972 & 0.974 & -0.36 & 20.4 & 28.3 & \\
\hline & & & 12 & $d, h$ & 0.975 & 0.983 & -5.20 & 15.5 & 23.1 & \\
\hline & & & 13 & $d, \mathrm{cl}, h(\mathrm{NLM})$ & 0.980 & 0.981 & -13.02 & 18.3 & 17.3 & 1050.5 \\
\hline & & & 14 & $d, h, h_{\mathrm{dom}}$ & 0.982 & 0.983 & -10.65 & 18.6 & 25.6 & \\
\hline & & Total & 15 & $d, h, h_{\mathrm{dom}}$ & 0.981 & 0.982 & -16.59 & 21.2 & 18.6 & 1089.2 \\
\hline & \multirow[t]{11}{*}{ Simultaneous } & Leaves & 1 & $d$ & 0.818 & 0.858 & -0.21 & 1.90 & 2.9 & \\
\hline & & & 2 & $d, G$ & 0.822 & 0.894 & -0.23 & 2.00 & 2.9 & \\
\hline & & & 3 & $d, \mathrm{cl}$ & 0.839 & 0.897 & -0.13 & 1.90 & 2.7 & \\
\hline & & & 5 & $d, \mathrm{cl}, h_{\mathrm{dom}}$ & 0.850 & 0.906 & -0.60 & 1.90 & 2.6 & \\
\hline & & Branches & 6 & $d$ & 0.911 & 0.91 & -0.31 & 3.80 & 5.6 & \\
\hline & & & 7 & $d, G$ & 0.911 & 0.919 & 0.95 & 3.90 & 5.6 & \\
\hline & & & 8 & $d, \mathrm{cl}$ & 0.943 & 0.939 & 0.69 & 3.10 & 4.5 & \\
\hline & & & 10 & $d, \mathrm{cl}, h_{\mathrm{dom}}$ & 0.949 & 0.935 & -0.22 & 3.00 & 4.3 & \\
\hline & & Stem (wood + bark) & 11 & $d$ & 0.974 & 0.974 & -0.33 & 19.8 & 27.9 & \\
\hline & & & 12 & $d, h$ & 0.983 & 0.983 & -5.05 & 14.9 & 22.5 & \\
\hline & & & 14 & $d, h, h_{\mathrm{dom}}$ & 0.983 & 0.983 & -10.52 & 18.1 & 22.5 & \\
\hline \multirow[t]{2}{*}{ Model comparison } & & Leaves & 1 & $d$ & 0.78 & 0.786 & 0.69 & 2.38 & 3.2 & \\
\hline & & & Ref 1 & $d$ & 0.798 & 0.785 & -0.30 & 2.37 & 3.4 & \\
\hline \multirow[t]{15}{*}{$(n=85)$} & & & 2 & $d, G$ & 0.716 & 0.740 & -2.15 & 3.70 & 2.5 & \\
\hline & & & $\operatorname{Ref} 2$ & $d, G$ & 0.608 & 0.677 & 0.48 & 4.31 & 6.3 & \\
\hline & & & 5 & $d, \mathrm{cl}, h_{\mathrm{dom}}$ & 0.839 & 0.853 & -0.88 & 1.92 & 2.6 & \\
\hline & & & $\operatorname{Ref} 3$ & $d, \mathrm{cl}, h_{\mathrm{dom}}$ & 0.703 & 0.846 & -1.73 & 2.61 & 5.4 & \\
\hline & & Branches & 6 & $d$ & 0.838 & 0.830 & 5.49 & 6.31 & 9.4 & \\
\hline & & & Ref 1 & $d$ & 0.739 & 0.896 & 14.41 & 14.41 & 11.3 & \\
\hline & & & 7 & $d, G$ & 0.790 & 0.909 & 6.64 & 7.27 & 10.5 & \\
\hline & & & $\operatorname{Ref} 2$ & $d, G$ & 0.554 & 0.861 & -7.45 & 10.40 & 13.9 & \\
\hline & & & 10 & $d, \mathrm{cl}, h_{\mathrm{dom}}$ & 0.917 & 0.932 & 0.26 & 4.36 & 6 & \\
\hline & & & $\operatorname{Ref} 3$ & $d, \mathrm{cl}, h_{\mathrm{dom}}$ & 0.697 & 0.896 & 11.36 & 11.44 & 14.6 & \\
\hline & & Stem (wood + bark) & 12 & $d, h$ & 0.960 & 0.964 & 1.24 & 24.16 & 31.3 & \\
\hline & & & Ref 1 & $d, h$ & 0.894 & 0.974 & 18.58 & 25.37 & 34 & \\
\hline & & & $\operatorname{Ref} 2$ & $d, h$ & 0.938 & 0.967 & 27.92 & 35.80 & 43.6 & \\
\hline & & & 14 & $d, h, h_{\mathrm{dom}}$ & 0.961 & 0.963 & 5.39 & 23.97 & 33 & \\
\hline & & & $\operatorname{Ref} 3$ & $d, h, h_{\mathrm{dom}}$ & 0.939 & 0.972 & 1.14 & 28.13 & 40.4 & \\
\hline
\end{tabular}

Refs 1, 2, and 3 are Pérez-Cruzado et al. (2011), Merino et al. (2005), and António et al. (2007) studies, respectively. Equations tested in the model comparison are from the simultaneous adjustment

$d$ diameter at breast height $(\mathrm{cm}), c l$ tree crown length $(\mathrm{m}), h$ tree height $(\mathrm{m}), h_{\text {dom }}$ dominant height $(\mathrm{m}), G$ basal area $\left(\mathrm{m}^{2} / \mathrm{ha}\right), E$ modeling efficiency, $R^{2}$ coefficient of determination between the measured and estimated values, model bias (mean of the press residuals), $|r|$ model precision (mean of the absolute values of the press residuals), RMSE root-mean-square error, AIC Akaike information criteria 
Fig. 2 Observed and predicted leaf, branch, and stem (wood + bark) biomass utilizing the simultaneous adjustment equations 5,10 , and 14 for the model calibration data $(n=145)$. $W l$ leaf biomass (kg, dry matter), $W b$ branch biomass (kg, dry matter), $O B S$ measured values, $P R E D$ predicted values, $R^{2}$ coefficient of determination, defined as the square correlation coefficient between the measured and estimated values
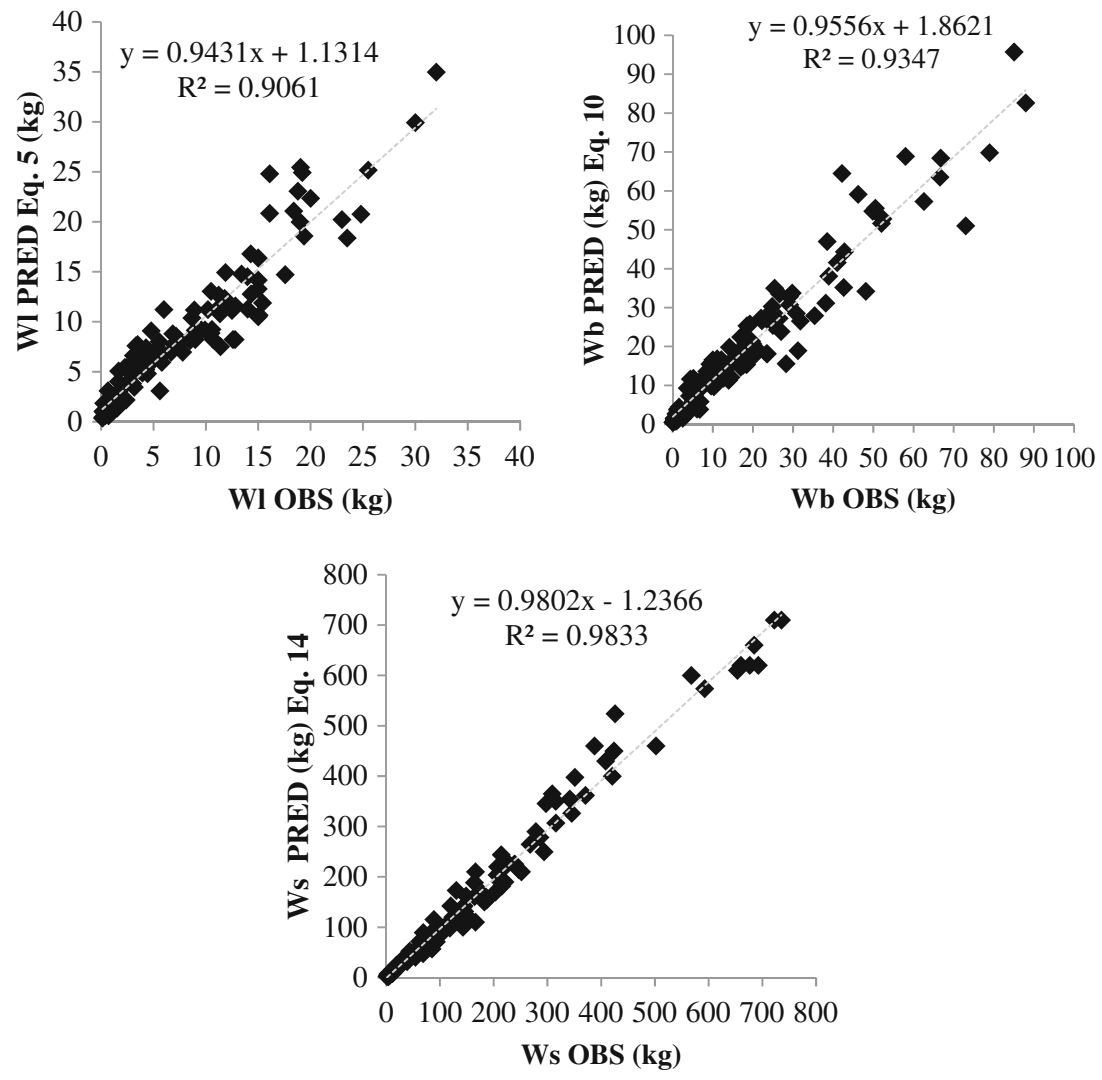

Fig. 3 Observed and predicted leaf and branch biomass utilizing the simultaneous adjustment Eqs. 1, 2, 5, 6, 7, and 10 and the literature models from the references 1-3 for the model comparison data $(n=85)$. $W l$ leaf biomass (kg, dry matter), $\mathrm{Wb}$ branch biomass (kg, dry matter), $P R E D$ predicted values, $O B S$ measured values, $R^{2}$ coefficient of determination, defined as the square correlation coefficient between the measured and estimated values. Refs 1, 2, and 3 are studies of Pérez-Cruzado et al. (2011), Merino et al. (2005), and António et al. (2007), respectively

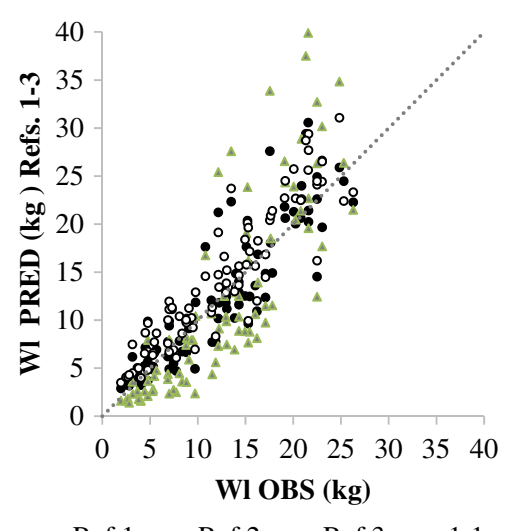

- $\operatorname{Ref} 1 \quad \Delta \operatorname{Ref} 2 \quad \circ \operatorname{Ref} 3 \quad 1: 1$

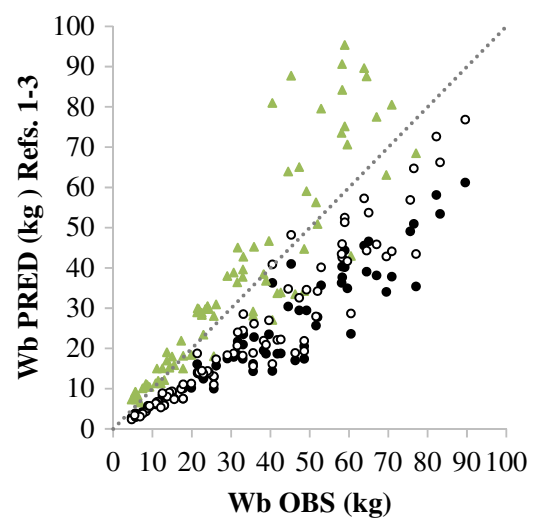

- Ref. $1 \quad \Delta$ Ref. $2 \quad \circ$ Ref. $3 \quad 1: 1$

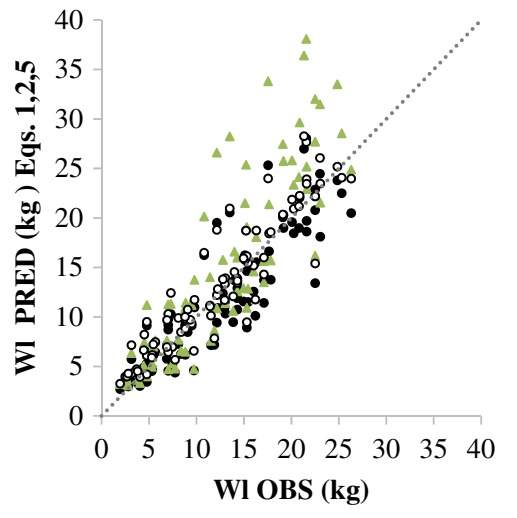

- Eq. $1 \Delta$ Eq. 2 ०Eq. $5 \quad 1: 1$

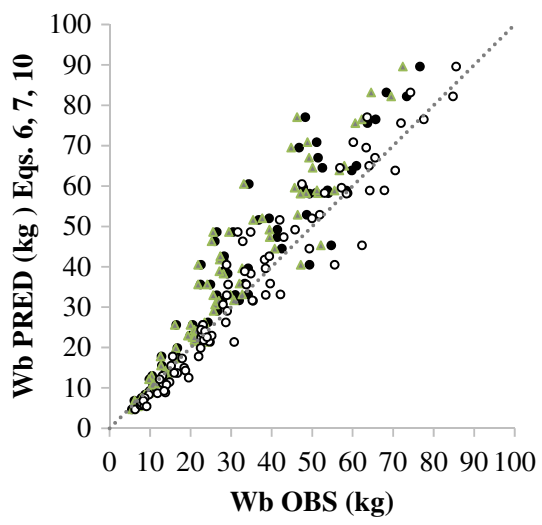

- Eq. $6{ }^{\Delta}$ Eq. 7 ○Eq. 10 
Table 4 Allometries of root biomass and root to shoot $(\mathrm{R} / \mathrm{S})$ ratios for planted and coppice trees

\begin{tabular}{|c|c|c|c|c|c|c|c|c|c|c|}
\hline Rotation & $\begin{array}{l}\text { Predicted } \\
\text { variable }\end{array}$ & Equation & Eq.N & $a_{\mathrm{r}}$ & $b_{\mathrm{r}}$ & $k_{\mathrm{r}}$ & $c$ & $E$ & $R^{2}$ & RMSE \\
\hline \multirow[t]{2}{*}{ Planted } & Root biomass & $\mathrm{WR}=a_{\mathrm{r} 1}+b_{\mathrm{r} 1} \ln (d)$ & 19 & $\begin{array}{r}-430.4512 \\
\quad(55.0978)\end{array}$ & $174.3656(19.1802)$ & & & 0.886 & 0.887 & 19.71 \\
\hline & $\mathrm{R} / \mathrm{S}$ ratio & $\mathrm{R} / \mathrm{S}=k_{\mathrm{rs} 1} \exp ^{\left(c^{*} d\right)}$ & 20 & & & $1.0291(0.1588)$ & $-0.0352(0.0039)$ & 0.880 & 0.88 & 0.05 \\
\hline \multirow[t]{2}{*}{ Coppice } & Root biomass & $\mathrm{WR}=a_{\mathrm{r} 2}+b_{\mathrm{r} 2} \ln (d e q)$ & 21 & $\begin{array}{r}-578.3233 \\
(71.134)\end{array}$ & $280.285(25.226)$ & & & 0.826 & 0.824 & 41.30 \\
\hline & $\mathrm{R} / \mathrm{S}$ ratio & $\mathrm{R} / \mathrm{S}=k_{\mathrm{rs} 2} \exp ^{\left(c^{*} d e q\right)}$ & 22 & & & $3.0493(0.504)$ & $-0.045(0.006)$ & 0.824 & 0.83 & 0.20 \\
\hline
\end{tabular}

$W R$ root biomass ( $\mathrm{kg}$ dry matter), $R / S$ root to shoot ratio, $d$ diameter at breast height $(\mathrm{cm})$, deq equivalent diameter at breast height of the same basal area as the sum of basal areas of the coppiced shoots of one tree root, $E q$. $N$ equation number, $E$ modeling efficiency, $R^{2}$ coefficient of determination between the measured and estimated values, RMSE root-mean-square error

height) improved the models. This response is consistent with that observed for E. globulus by Antonio et al. (2007) in Portugal and by Zewdie et al. (2009) in Ethiopia and for other Eucalyptus spp. elsewhere (Bi et al. 2004; Montagu et al. 2005; Williams et al. 2005; Paul et al. 2008).

Our results indicate that biomass regional studies need to take into account the influence of site characteristics, especially when they are contrasted. The nlme approach highlighted the importance of considering the site variability through a random factor in the leaf and branch models. As the authors know, the latter approach has not been still used for E. globules, although studies have underlined its utility in other species (Schneider et al. 2008; Repola 2009; Fu et al. 2014; Smith et al. 2014). Moreover, increases in modeling efficiency were slightly higher when a specific site parameter (dominant height) was included in the exponent of the diameter at breast height, in the NSUR approach, as Antonio et al. (2007) did. The effect was most pronounced for leaf and branch fractions, more sensitive to both, environmental conditions and stand development stage in Eucalyptus spp. (Bi et al. 2004; Saint-André et al.
2005; Antonio et al. 2007) and other species (BondLamberty et al. 2002; Wutzler et al. 2008; Genet et al. 2011).

\subsection{Aboveground biomass allometries: validation}

A relatively good quality of fitting was obtained in the validation process when using equations constructed with the calibration dataset, following the equation structures proposed by Merino et al. (2005), Antonio et al. (2007), and Pérez-Cruzado et al. (2011), respectively. This quality of performance was higher than that obtained by using directly their models. This was expected given that calibration dataset was the same for the three equations whereas different datasets were used by each author for his own model development. The allometries from the work of Merino et al. (2005), derived from E. globulus stands at harvesting age, resulted in an underestimation of leaf biomass (Fig. 3). This could be explained by a lower allocation to leaf biomass in the trees utilized in his study, compared to a higher allocation to leaf biomass predicted by the equations of Pérez-Cruzado et al. (2011), which were derived on younger plantations. Several studies (SaintAndré et al. 2005; Fontes et al. 2006; Antonio et al. 2007)
Fig. 4 Measured and predicted root biomass (left) and root to shoot $(\mathrm{R} / \mathrm{S})$ ratios (right) against tree diameter for planted and coppiced trees. $d$ diameter at breast height $(\mathrm{cm})$ or equivalent diameter $d e q$ for coppice tress, $W R$ root biomass (kg dry matter), $R / S$ root to shoot ratio, $P R E D$ predicted values, $O B S$ measured values
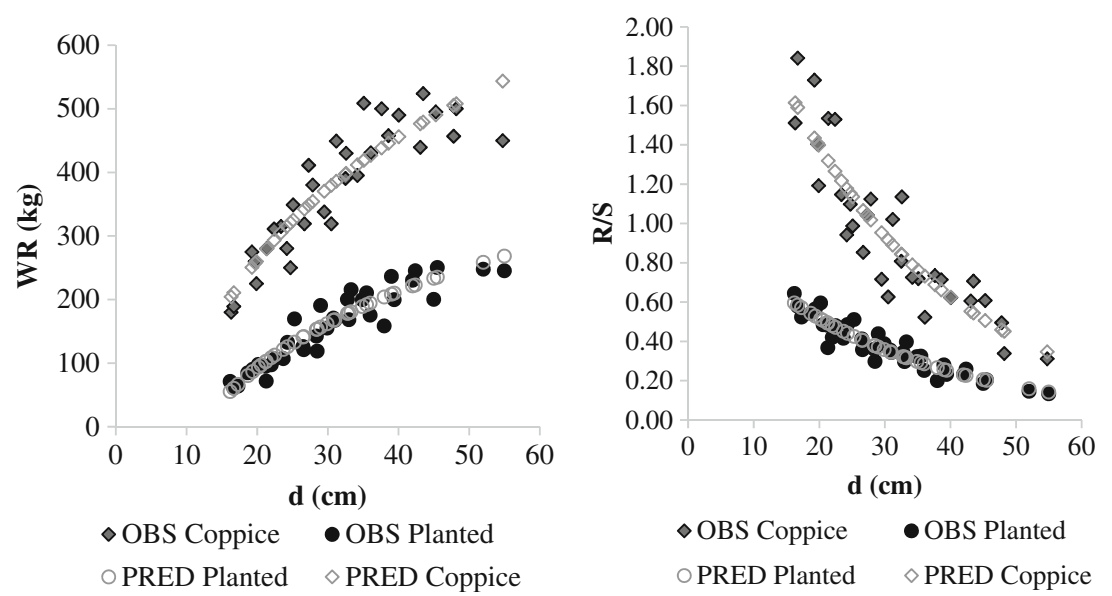
have found a higher leaf biomass allocation for younger eucalypt trees, declining with age and level out at a lower proportion for older stands. The overestimation in leaf biomass observed in the predictions of the model of Antonio et al. (2007) could be explained by the higher degree of defoliation present in NW Spain E. globulus stands caused by Gonipterus scutellatus (Cordero and Santolamazza 2000; Fernandez et al. 2011) compared to Portuguese stands.

In the case of branches, the equations of Pérez-Cruzado et al. (2011) and Merino et al. (2005) resulted in overestimations and underestimations of the branch biomass, possibly due to the absence of crown length and stand dominant height in these models to account for the effects of age, site quality, and competition on the crown development of the trees. The underestimation of branch biomass of the equation of Antonio et al. (2007) exemplifies the problems commonly related in the literature (e.g., Bi et al. 2004; Williams et al. 2005; Zianis et al. 2011; Smith et al. 2014) related to extrapolate allometric biomass functions from one region to another one. This may be particularly pronounced for species covering a wide extension such as E. globulus and growing on an ample range of environmental conditions in the study area, resulting in potentially different biomass allocation patterns.

Very similar predictions were obtained for the stem biomass models, supporting previous findings regarding that tree stem is the biomass component less sensitive to environmental and stand development conditions (Bi et al. 2004; Saint-André et al. 2005; Antonio et al. 2007),

\subsection{Belowground biomass allometries for planted and coppiced stands}

The response of belowground biomass as a function of diameter showed an increase up to about $40 \mathrm{~cm}$ in diameter, followed by a leveling out both in planted and coppice trees (Fig. 4). This tendency is contrary to that previously found in E. globulus (Resh et al. 2003; O'Grady et al. 2006; Herrero et al. 2014) and in other eucalypt species (Misra et al. 1998; Bernardo et al. 1998; Saint-André et al. 2005; Paul et al. 2008; Jonson and Freudenberger 2011; Razakamanarivo et al. 2012; Kuyah et al. 2013).

Our finding seems to suggest that once the trees have established a maximum root system that allows for an efficient exploration of the available space for water and nutrient acquisition, the root growth tends to stabilize, although more research on this topic is still necessary.

Our model predicting R/S variability with tree diameter for coppice and planted E. globulus trees is a significant step forward for a better knowledge of the biomass allocation pattern in that species. This trend suggests that, whereas the aboveground biomass growth continues, belowground stabilizes, resulting in decreasing $\mathrm{R} / \mathrm{S}$ ratios with increasing tree size. The range of $\mathrm{R} / \mathrm{S}$ of our data, in planted trees $(0.15$ to
0.65), was very similar to those reported by Cairns et al. (1997), for many tropical, temperate boreal species $(0.1$ to 0.6), and Bernardo et al. (1998) (0.2 to 0.6) for several eucalypt species in Brazil. A number of authors have reported decreasing $R / S$ values with tree size or aboveground biomass (Misra et al. 1998; Levillain et al. 2011; Resh et al. 2003; Kuyah et al. 2013) or age (Laclau et al. 2000; Soares and Tomé 2012) in eucalypt. However, studies modeling the belowground biomass and R/S ratios as a function of dendrometric variables are extremely scarce in eucalypt species (Paul et al. 2008; Jonson and Freudenberger 2011), and they show the same trend with diameter than in our study.

Higher R/S values measured in the coppice trees ( 0.31 to 1.83) than in planted trees were expected, given the fact that there is already an established root system from the previous rotation, and E. globulus has a well-developed lignotuber. This is consistent with recent observations of Kuyah et al. (2013), with $\mathrm{R} / \mathrm{S}$ values higher than 0.5 , and lower than Herrero et al. (2014), who found R/S between 0.1 and 4.6, and Razakamanarivo et al. (2012), ranging from 2 to 5.

\section{Conclusions}

The allometries presented in this study are the first available models considering crown length for the estimation of branch and leaf biomass of E. globulus in northern Spain. Our study confirms the improvement in the estimation of biomass components obtained with the use of this variable. Higher efficiency of the models, when site or stand dominant height was included, revealed the importance of stand characteristics and environmental conditions on the biomass partitioning pattern. This fact has also been reinforced by the better performance of models constructed with the dataset of the same region than those used in the validation process, compared with those developed in other regions. Depending on the degree of accuracy pursued, the necessity of incorporating crown length, site, and environmental variables in the prediction equations has to be balanced with the sampling costs.

We provided the first available models for E. globulus belowground biomass prediction for both, planted and coppice trees, in Galicia, region where it covers about 310,000 ha. Belowground biomass could be successfully modeled from easily measurable variables, showing a tendency for increasingly lower allocation in larger trees, a fact not observed until now. High values of root biomass in the coppiced trees were also found. Our results can be useful for carbon stockage and sequestration assessments in those fast-growing plantations. Future works might focus on validating the presented belowground biomass models, incorporating fine root estimation, and in covering the biomass allocation through several coppice cycles. 
Acknowledgments The involvement of the personnel from the Lourizán Forest Research Centre, Xunta-Government of Galicia, Spain, in the biomass sampling and data processing is thankfully acknowledged. The authors would like to acknowledge the companies and landowners involved in the biomass sampling. We thank Christopher Martyn Rich for revising the English of the document. We would also like to sincerely thank two anonymous reviewers and handling editor for their useful comments and suggestions, which helped to improve an earlier version of the manuscript.

Funding Financial support from CATEDRA ENCE from the pulp and energy company ENCE is acknowledged for the current study.

\section{References}

Agencia Estatal de Meteorología, Ministerio de Medio Ambiente y Medio Rural y Marino-Gobierno de España, Instituto de Meteorología de Portugal., 2011. Atlas Climático Ibérico., 19712000., $80 \mathrm{p}$

Antonio N, Tomé M, Tomé J, Soares P, Fontes L (2007) Effect of tree, stand, and site variables on the allometry of Eucalyptus globulus tree biomass. Can J For Res 37:895-906

Bernardo AL, Reis MGF, Reis GG, Harrison RB, Firme DJ (1998) Effect of spacing on growth and biomass distribution in Eucalytpus camaldulensis, E. pellita and Europhylla plantations in southeastern Brazil. For Ecol Manag 104:1-13

Bi H, Turner J, Lambert MJ (2004) Additive biomass equations for native eucalypt forest trees of temperate Australia. Trees 18:467-479

Bond-Lamberty B, Wang C, Gower ST (2002) Above-ground and belowground biomass and sapwood area allometric equations for six boreal tree species of northern Manitoba. Can J For Res 32:1441-1450

Brañas J, González-Río F, Merino A (2000) Contenido y distribución de nutrientes en plantaciones de Eucalyptus globulus del Noroeste de la Península Ibérica. Investigación Agraria: Sist y Rec For 9:316-335

Cairns MA, Helmer EH, Baumgardner GA (1997) Root biomass allocation in the world's upland forests. Oecologia 111:1-11

Cordero A, Santolamazza S (2000) The effect of three species of Eucalyptus on growth and fecundity of the Eucalyptus snout beetle, Gonipterus scutellatus. Forest 73:21-29

DGCN. Cuarto Inventario Forestal Nacional, Galicia. Ministerio de Agricultura, Alimentación y Medio Ambiente, Madrid., 2012. 49 pp. [Fourth National Inventory, Galicia. Ministry of Agriculture, Food and Environment. In Spanish]

Fernandez C, Vega JA, Bará S, Alonso M, Fontúrbel T (2011) Absence of effects on nutrient budgets after insect defoliation in a small E. globulus watershed in Galicia., NW Spain. For Syst 20:228-234

Fontes L, Landsberg J, Tome J, Tome M, Pacheco CA, Soares P, Araujo C (2006) Calibration and testing of a generalized process-based model for use in Portuguese eucalyptus plantations. Can J For Res 36: 3209-3221

Fu L, Zeng W, Zhang H, Wang G, Lei Y, Tang S (2014) Generic linear mixed-effects individual-tree biomass models for Pinus massoniana in southern China. South For 76:47-56

Genet A, Wernsdörfer H, Jonard M, Pretzsch H, Rauch M, Ponette Q, Nys C, Legout A, Ranger J, Vallet P, Saint-André L (2011) Ontogeny partly explains the apparent heterogeneity of published biomass equations for Fagus sylvatica in central Europe. For Ecol Manag 261:1188-1202

Harvey AC (1976) Estimating regression models with multiplicative heterocedasticity. Econometrica 44:461-465

Herrero C, Juez L, Tejedor C, Pando V, Bravo F (2014) Importance of root system in total biomass for Eucalyptus globulus in northern Spain. Bio Bioen 67:212-222
Jonson JH, Freudenberger D (2011) Restore and sequester: estimating biomass in native Australian woodland ecosystems for their carbon-funded restoration. Aust J Botany 59:639-652

Kuyah S, Dietz J, Muthuri C, van Noordwijk M, Neufeldt H (2013) Allometry and partitioning of above- and below-ground biomass in farmed eucalyptus species dominant in Western Kenyan agricultural landscapes. Bio Bioen 55:276-284

Laclau JP, Jean-Pierre B, Ranger J (2000) Dynamics of biomass and nutrient accumulation in a clonal plantation of Eucalyptus in Congo. For Ecol Manag 128:181-196

Levillain J, M'Bou AT, Deleporte P, Saint-André L, Jourdan C (2011) Is the simple auger coring method reliable for below-ground standing biomass estimation in Eucalyptus forest plantations? Ann Bot 108:2011

Merino A, Balboa MA, Rodríguez-Soalleiro R, Álvarez-González JG (2005) Nutrient exports under different harvesting regimes in fastgrowing forest plantations in southern Europe. For Ecol Manag 207: 325-339

Misra RK, Turnbull CRA, Cromer RN, Gibbons AK, LaSala AV (1998) Below- and above-ground growth of Eucalyptus nitens in a young plantation I. Biomass. For Ecol Manag 106:283-293

Montagu KD, Düttmer K, Barton CVM, Cowie AL (2005) Developing general allometric relationship for regional estimates of carbon sequestration - an example using Eucalyptus pilularis from seven contrasting sites. For Ecol Manag 204:113-127

Montero G, Ruiz-Peinado R, Muñoz M (2005) Producción de biomasa y fijación de $\mathrm{CO} 2$ por los bosques españoles. Madrid: Instituto Nacional de Investigación y Tecnología Agraria y Alimentaria. Monografías INIA: Serie Forestal Report 13, 220 p

Myers R (1990) Classical and modern regression with applications. PWS Publishers, Boston

O'Grady AP, Worledge D, Battaglia M (2006) Above- and below-ground relationships, with particular reference to fine roots, in a young Eucalyptus globulus Labill stand in southern Tasmania. Trees 20: $531-538$

Pardé J, Bouchon J (1988) Dendrométrie, 2nd edn. ENGREF, Nancy

Parresol BR (1999) Assessing tree and stand biomass: a review with examples and critical comparisons. For Sci 45:573-593

Parresol BR (2001) Additivity of nonlinear biomass equations. Can J For Res 31:865-878

Paul KI, Jacobsen K, Koul V, Leppert P, Smith J (2008) Predicting growth and sequestration of carbon by plantations growing in regions of low-rainfall in southern Australia. For Ecol Manag 254:205-216

Pérez-Cruzado C, Merino A, Rodríguez-Soalleiro R (2011) A management tool for estimating bioenergy production and carbon sequestration in Eucalyptus globulus and Eucalyptus nitens grown as short rotation woody crops in north-west Spain. Biom Bioen 35: 2839-2851

Pinheiro JC, Bates DM (2000) Mixed-effects models in S and S-PLUS. Springer Verlag, New York

Pinheiro JC, Bates DM, DebRoy S, Sarkar D, The R Development Core Team (2012) nlme: linear and nonlinear mixed effects models. R package version 3. 1-104

Razakamanarivo RH, Razakavololona A, Razafindrakoto MA, Vieilledent G, Albrecht A (2012) Below-ground biomass production and allometric relationships of eucalyptus coppice plantation in the central highlands of Madagascar. Biom Bioen 45:1-10

Repola J (2009) Biomass equations for Scots pine and Norway spruce in Finland. Silva Fennica 43:625-647

Resh SC, Battaglia M, Worledge D, Ladiges S (2003) Coarse root biomass for eucalypt plantations in Tasmania, Australia: sources of variation and methods of assessment. Trees 17:389-399

Ruiz-Peinado R, Montero G, del Rio M (2012) Biomass models to estimate carbon stocks for hardwood tree species. For Sys 21:42-52

Saint-André L, M'bou AT, Mabiala A, Mouvondy W, Jourdan C, Roupsard O, Deleporte P, Hamel O, Nouvellon Y (2005) Age- 
related equations for above- and belowground biomass of a Eucalyptus hybrid in Congo. For Ecol Manag 205:199-214

SAS Institute Inc (2004) SAS/ETS ${ }^{\circledR} 9.1$ user's guide. SAS Institute Inc., Cary

Schneider R, Berninger F, Ung CH, Bernier PY, Swift DE, Zhang SY (2008) Calibrating jack pine allometric relationships with simultaneous regressions. Can J For Res 38:2566-2578

Smith A, Granhus A, Astrup R, Bollandsas OM, Petersson H (2014) Functions for estimating aboveground biomass of birch in Norway. Scand J For Res 29:565-578

Snowdon P, Raison J, Keith H, Grierson P, Adams MA, Montagu K, Huiquan B, Burrows W, and Eamus D (2002) Protocol for sampling tree and stand biomass. Tech Rep No. 31. Australian Greenhouse Office, Canberra

Soares P, Tomé M (2012) Biomass expansion factors for Eucalyptus globulus stands in Portugal. For Syst 21:141-152

Soares P, Tome M, Skovsgaard JP, Vanclay JK (1995) Evaluating a growth model for forest management using continuous forest inventory data. For Ecol Manag 71:251-265

Vega-Nieva DJ, Dopazo R, Ortiz L (2008) Reviewing the potential of forest bioenergy plantations: woody energy crop plantations management and breeding for increasing biomass productivity. In: World Bioenergy 2008. Jönköping, Sweden, 27-29

Viana H, Cohen WB, Lopes D, Aranha J (2010) Assessment of forest biomass for use as energy. GIS-based analysis of geographical availability and locations of wood-fired power plants in Portugal. App En 87:2551-2560

Viana H, Vega-Nieva DJ, Ortiz L, Lousada J, Aranha J (2012) Fuel characterization and biomass combustion properties of selected native woody shrub species from central Portugal and NW Spain. Fuel 102:737-745

Williams RJ, Zerihun A, Montagu KD, Hoffman M, Hutley LB, Chen X (2005) Allometry for estimating aboveground tree biomass in tropical and subtropical eucalypt woodlands: towards general predictive equations. Aust J Bot 53:607-619

Wutzler T, Wirth C, Schumacher J (2008) Generic biomass functions for common beech., Fagus sylvatica. in Central Europe: predictions and components of uncertainty. Can J For Res 38:1661-1675

Zewdie M, Olsson M, Verwijst T (2009) Above-ground biomass production and allometric relations of Eucalyptus globulus Labill. coppice plantations along a chronosequence in the central highlands of Ethiopia. Biom Bioen 33:421-428

Zianis D, Xanthopoulos G, Kalabokidis K, Kazakis G, Ghosn D, Roussou O (2011) Allometric equations for aboveground biomass estimation by size class for Pinus brutia Ten. trees growing in North and South Aegean Islands, Greece. Eur J For Res 130:145-160 